\title{
Speech Act Analysis on Walt Disney Film Entitled 'Frozen'
}

\author{
(A Pragmatic Study)
}

\author{
Sukasih Ratna Widayanti \\ Universitas Widya Dharma \\ English Education Study Program, FKIP \\ Klaten, Indonesia \\ sukasihratnawidayanti@yahoo.com
}

\author{
Kustinah \\ Universitas Widya Dharma \\ English Education Study Program, FKIP \\ Klaten, Indonesia \\ kustinahunwidha@gmail.com
}

\begin{abstract}
Film as one media of communication can deliver message to the audience. It has various genre which becomes interesting subject to investigate. The utterance on the film, especially children genre, which is used by the character can influence the language acquisition on children when they watch the film. This study tries to identify the types of speech act on film entitled Frozen through pragmatics approach. This film is chosen since it is very famous and one representation of children genre. This is descriptive qualitative study which reveals the data through the transcript of the utterance in the film entitled Frozen. In collecting the data, the writers transcribed the data comprehensively. The writers analyse the data of the speech act types on film entitled Frozen. There are four types of speech act which occur on film entitled Frozen. Those types are representative, expressive, directive, and commisive. Children can imitate and adopt those utterances which indicate one or more types of speech act. It gives the contribution to the children language acquisition.
\end{abstract}

Keywords—linguistics; pragmatics; speech act; film

\section{INTRODUCTION}

As a piece of literary works such as drama and novel, film consists of dialogues among its characters. Through dialogues among each character, we can get the message from the film. It means that film as one media of communication is used to as the media of delivering message. The message in a film can be form in words, phrases, clauses, and sentences. Those are the spoken discourse which consists of various kinds of speech acts. One character in the film can perform many acts while he or she conveys some utterances. The characters have roles to show the information.

Frozen is one film which produced by Walt Disney Animation Studios. It released in 2013 by Walt Disney Pictures. It is one famous film which is inspired by Hans Christian Andersen's fairy tale entitled The Snow Queen. It tells the story of a fearless princess who sets off on a journey alongside a rugged iceman, his loyal reindeer, and a snowman to find her sister who have the icy power. Her sister have trapped their kingdom in the eternal winter through the power. Frozen is also one representation of children genre film.
Concerning the speech acts, there is a phenomenon in Walt Disney film entitled Frozen regarding how speech acts are commonly used in the film. It is chosen as the object of the study since it has many dialogues in the form of utterances which can be analysed on the speech acts aspects. It is also a well-known film which has already won some awards, such as two Academy Award, the Golden Globe Award for Best Animated Feature, BAFTA Award for Best Animated Film, five Annie Award, and two Critics' Choice Award.

This study deals with speech acts, the writers formulate a problem of the study as follow. 'What are the types of speech acts on the film entitled Frozen?' Related to the formulation as stated before, the objective of this study tries to identify the types of speech acts on the film entitled Frozen.

\section{LITERATURE REVIEW}

\section{A. Pragmatic}

There are some points of view on pragmatics. According to Yule (1996, p. 3), firstly, pragmatics is the study of speaker's meaning. It is concerned with the study of meaning as communicated by a speaker (or writer) and interpreted by a listener (or reader). Secondly, pragmatics is the study of contextual meaning which involves the interpretation of what people mean in a particular context and how the context influences what is said. It requires a consideration of how speakers organize what they want to say appropriately to whom they are talking to, where, when, and in what situation. Thirdly, pragmatics is the study of how more gets communicated than is said. It explores how listeners can make inferences about what is said in order to arrive at an interpretation of the speaker's intended meaning. Lastly, pragmatics is the study of the expression of relative distance. It is regarded as the study of the relationship between linguistic forms and the users of those forms.

Leech $(1983$, p. 6) states that pragmatics is the study of meaning in relation to speech situations. It means that we are dealing with pragmatics if one or more of aspects of speech situation are fulfilled. Further, he defines pragmatics as problem-solving both from the speaker's and the hearer's point of view. From the speaker's, the problem is one planning 
about how to produce one utterance which will make the result most likely, whereas from the hearer's point of view, the problem is an interpretive one, where the hearer should interpret what the most likely reason for the speaker in saying the utterance.

According to Mey (2001, pp. 4-5), pragmatics tells about the right to use language in various, unconventional ways, as long as people know what they are doing to deliver their purposes. Widdowson (1996, p. 61) also adds that pragmatics is the concern of what people mean by the language they use or how they actualize its meaning potential as a communicative resource. It studies the expression in an actual utterance in a specific context to achieve the intended message in a communication since people may not know what might be meant by the expression. In conclusion, pragmatics is the study of meaning of utterances in relation to the contexts which involves how speakers produce an utterance to deliver their intention and how the listeners interpret it.

\section{B. Speech Act}

According to Nunan (1993, p. 65), speech acts are simply things people do through language, for example, apologizing, complaining, instructing, agreeing, and warning. Searle (1969, p. 16) defines that the production or issuance of a sentence taken under certain conditions is a speech act, and speech acts are the basic or minimal units of linguistic communication. Speaking a language is performing speech acts, such as making statements, giving command, asking questions, making promises, and etc.

Grundy (2008, p. 71) states that speech acts are language as action. Speech acts, which explore the performative nature of utterances, are the ways in which what people say to each other has force as well as content. There is an intention as content of what people say that is delivered via language with its force to get the message inside the utterances. However, language is the principal means that people have to greet, compliment and insult one another, to plead or flirt, to seek and supply information, and to accomplish hundreds of other tasks in a typical day.

Furthermore, Austin (1962, p. 98-101) states that speech acts consist of three related acts as follows. Firstly, locutionary act is the act of saying something. It is concerned with meaning. He notes meaning as the use of language with a certain sense and reference. Secondly, illocutionary act is the act performed in saying something. The act is identified by the explicit performative. Thirdly, perlocutionary act is the act performed by or as a result of saying. In saying something, we produce certain consequential effects upon the feelings, thoughts, or actions of the audience or the speaker.

Cruse (2006, p. 167-169) also agreed with Austin. He describes that speech act is acts which crucially involve the production of language. It is usual to recognize three basic types: locutionary acts, illocutionary acts and perlocutionary acts. Locutionary act is the production of an utterance, with a particular intended structure, meaning, and reference. These provisos are meant to rule out the mindless production of language such as by parrots and computers.
Illocutionary act is an act performed by a speaker in saying something (with an appropriate intention and in an appropriate context), rather than by virtue of having produced a particular effect by saying something. For instance, if someone says 'I order you to leave now.' they have performed the act of ordering, simply by virtue of having uttered the words, whether or not the addressee acts in the desired way.

Perlocutionary act is a speech act which depends on the production of a septic effect. For instance, for the verbal act of persuasion to have occurred, in Pete persuaded Liz to marry him, it is not enough for Pete to have uttered certain words what is essential is that a previously reluctant addressee is caused to act in an appropriate way.

Every illocutionary act has a particular 'illocutionary force'. This may be explicitly signaled by the use of a performative verb such as beg, promise, command, suggest, congratulate, or thank, or a particular grammatical form, as in 'Go away!', 'Have you seen Pete?', or it may be implicit, in which case it must be inferred, largely on the basis of contextual evidence. For instance, an utterance such as 'You will never see me again.' may function, in different circumstances, as a threat, a promise, a simple statement of fact, or a prediction. For a particular illocutionary act to function normally, it is typically the case that certain contextual conditions need to be satisfied. These conditions are known as felicity conditions.

While Searle in Leech (1983, p. 105) states that the classification of illocutionary acts is based on varied criteria. He divides speech act into five main types. They are declaratives, representatives, expressive, directives, and commisives.

Declaratives are speech acts whose effects immediately change an institutional state of affair and which tend to rely on elaborate extra-linguistic institutions. Some paradigm cases are excommunicating, declaring war, christening, marrying, and firing from employment. In order to perform a declaration appropriately, the speaker has to have a special institutional role in a specific context. These acts are normally performed by someone who is especially authorized to do so within some institutional framework such as judges sentencing offenders. When the speaker utters a declaration, his or her words bring about a new state of affair. Some examples are as follow. (1) Priest: I now pronounce you husband and wife. (2) Judge: This court sentences you to ten years imprisonment. Those examples change the world via utterance. In example (1), the priest changes the life of two persons of a single being to be husband and wife as a new family. While in example (2), the court which is led by a judge makes a free-man to be imprisoned-man.

Representatives are acts which commit the speaker to the truth of the expressed proposition. Some paradigm cases are asserting and concluding. Leech (1983, p. 105) proposes the examples of this acts are such as stating, suggesting, boasting, complaining, claiming, and reporting. The acts are used by the speaker to represent a state of affairs (Finnegan et.al, 1997, p. 344). In uttering a representative, a speaker conveys his/her belief that some proposition is true. The words used by the speaker state what the speaker believes to be the case, such as 
describing, claiming, hypothesizing, insisting, and predicting (Cutting, 2008, p. 14). He gives an example taken from Boston.com News as follows "I think girls work harder than boys. Maybe not doing your work is sign of being cool", said Jack Niveson. Jack Niveson applies representative since what his utterances show are his opinions or his belief. Other examples are as follow. (1) The earth is flat. The first example represents the world as he/she believes it is. The speaker states his/her belief that the earth is flat as the true one. (2) It was a warm sunny day. This second example also represents the world as he/she believes it is. The speaker describes his/her opinion that the day is warm and sunny as his/her belief although maybe it is a hot sunny day. In using a representative, the speaker makes words fit the world.

Expressive is one type of speech acts which expresses a psychological state. Some paradigm cases are greeting, thanking, apologizing, complimenting, stating pleasure, stating pain, stating doubt, stating, confusing, stating surprise, stating surrender, stating fear, stating panic, stating anger, and stating dislike. They have the function of expressing, or making known, the speaker's psychological attitude towards a state of affairs which the illocution presupposes. These speech acts express the speaker's inner state which says nothing about the world, such as thanking, congratulating, pardoning, blaming, praising, and condoling. Those psychological states can be statements of pleasure, pain, likes, dislikes, joy, or sorrow which are experienced by the speaker. Some examples are as follow. (1) I'm really sorry! The speaker expresses his/her psychological state of pardoning. (2) Congratulations! The speaker expressing his/her psychological state of congratulating. Both examples are spoken by the speaker to make words fit the world (of feeling) by uttering an expressive.

Directive is used by the speaker to get the addressee to do something. Some paradigm cases are requesting and questioning. It intends to produce some effects through action on the hearer. The speaker uses a directive to get the listener to do something by ordering, commanding, requesting, advising, and recommending. The speaker is also trying to get the listener to carry out some action. This act represents what the speaker wants. Gimme a cup of coffee. Make it black. The example shows the direction to the hearer to do what the speaker said that is to make a cup of coffee and to make it black. This speech act embodies an effort to direct the hearer towards the speaker's goal.

Commisives are acts which commit the speaker to some future course of action. Some paradigm cases are promising, threatening, and offering. By uttering commisives, the speaker is committing himself or herself to some future course of action, such as promising, vowing, offering, threatening, and refusing. Commisives express what the speaker intends. Some examples are as follow. (1) I'll be back. The speaker commits to the future action that he/she will come back again. (2) We will not do that. The speaker promises that he/she will not do the same thing again in the future. Both speakers are committing some future course of action which means they apply commisive. The speaker undertakes to make the world fit the words (via the speaker) by using commisive.

\section{Frozen}

Frozen released by Walt Disney Pictures in 2013. It is inspired by the fairy tale entitled The Snow Queen written by Hans Cristian Andersen. It tells about the kingdom named Arendelle who has two beautiful princesses. They are Prince Elsa of Arendelle, the princes with the icy power, and Prince Anna of Arendelle, the younger princess who is always cheerful.

Elsa accidentally injures Anna with her magic. Then, their parents, the King and Queen, take both siblings to a colony of trolls led by Grand Pabbie. He heals Anna, but alters her memories to remove traces of Elsa's magic, warning Elsa that she must learn to control her powers. Elsa has grown up to be a beautiful woman who would take the throne since her parents were died in the journey. She still cannot control her power. She ran away to the mountain to hide since she has made Arandelle become icy kingdom. She built her icy palace. Finally, Elsa can make the power more useful. She can control her magical power with warm heart. She accepted that she has a beautiful magical power which can make a now everywhere.

\section{METHOD}

This is a descriptive qualitative study which refers to a research procedure to produce a descriptive data, people's own written or spoken words, and observable behaviour (Bogdan and Taylor, 1975 , p. 4). This study describes the phenomenon of the types of speech acts in Walt Disney Film entitled Frozen uttered by the character. Bodgan and Biklen (1982, p. 28) state that the data descriptive qualitative research are in the form of words or pictures rather than in the form of numbers.

The main data of this study were dialogue transcript of the film. Since it is descriptive qualitative approach, the data were in the forms of lingual units, such as words, phrases, clauses, or sentences. The source of the data was Walt Disney Film entitled Frozen. The data collected from the utterances performed in the dialogues by the character in Frozen. The writers watch the film comprehensively in order to get a deep comprehension. They also try to find out the lingual units related to the objective of the study. They write the data and classify based on Searle's types of speech act.

The process of data analysis began when the writers collect the data. After the data identification, the data classify and analyse into their types of speech act. Then, the writers describe and interpret the data in order to answer the objective of the study.

\section{FINDINGS AND DISCUSSION}

In this part, the writers found four types of speech act in Walt Disney film entitled Frozen. They are representative, expressive, directive, and commisive. Below are the further explanation from the data in the film.

\section{A. Representative}

Representative conveys someone's belief that some proposition is true. Below is the example of the data that show the use of representative. 
The context of situation can be seen when the King, the Queen, Elsa, and Anna come to Grand Pibbie (the oldest troll who also have magical power) after the unfortunate accident happened to Anna who injured by Elsa's power.

Grand Pibbie : Your Majesty, born with the powers, or cursed?

King : Born, and they're getting stonger.

Grand Pibbie : Here, here. You are lucky it wasn't her heart. The heart is not so easily changed. But the head can be persuaded.

King : Do what you must.

From Grand Pibbie's utterance, representative speech act is occurred. It is in the form of sentence 'The heart is not so easily changed.' It is a belief in the Arendelle, the kingdom, that is truly happened when Elsa's magical power touch the heart of Anna. It makes not easy to heal since the heart is the most important thing in our life. It can feel the love and fear.

\section{B. Expressive}

Expressive express the psychological state. Below is the example of the data that indicate the use of expressive.

The context of situation is happened when Elsa and Anna played with Elsa's magical power. They were happy to play together with the snow. But, unfortunately Elsa injured Anna with her snowy power. The King and Queen heard Elsa's scream.

Elsa : Anna! Anna! Mama! Papa! No... No... You're okay, Anna. I got you.

King: Elsa, what you have done? This is getting out of hand.

Elsa : It was an accident. I'm sorry, Anna!

From the data above, Elsa says 'I'm sorry, Anna!' She tries to express her psychological state of pardoning. In this utterance, she feels really sorry about Anna's condition which is caused by her magical power. This data indicates the use of expressive in this film entitled Frozen.

\section{Directive}

Directive is is used by the speaker to get the addressee to do something. Below is the example of the data that show the use of directive.

The context of situation is occurred when the King, the Queen, Elsa, and Anna come to Grand Pibbie to ask for a help. They want to heal Anna from the accident.

Grand Pibbie : Listen to me, Elsa. Your power will only grow. There is beauty in it... but also great danger. You must learn to control it. Fear will be your enemy.

King : We'll protect her. She can learn to control it. I'm sure. Until then... we'll lock the gates. We'll reduce the staff. We will limit her contact with people, and keep her powers hidden from everyone, including Anna.

The King's utterances show the occurrence of directive speech act. The King says 'We'll protect her.' It means that he requests to protect Elsa from her power. Then, he adds 'we'll lock the gates.' It means that he also requests to close the gate to protect Elsa form other people. He also says 'We'll reduce the staff'. It means that the King request to minimize the amount of the staff in the kingdom in order to protect Elsa from her magical power. Finally he says 'We will limit her contact with people, and keep her powers hidden from everyone, including Anna.' It also King's request to make a boundary. He asks to other people not to keep contact with Elsa. He wants that nobody knows about Elsa's magical power, especially Anna, her sister since she ever injured by Elsa's power.

\section{Commisive}

Commisive commits the speaker to some future course of action. Below is the example of the data that indicate the use of commisive.

The context of situation is happened when a coronation party held in the Arandelle. Elsa becomes the Queen since her parent were passed away in the journey back home. There is one guest named Duke of Weaselton who have a conversation with Elsa.

Duke of Weaselton: Duke of Weaselton, Your Majesty. As your closest partner in trade. It seems only fitting that I offer you, your first dance as a queen.

Elsa : Uh... Thank you, only, I don't dance.

The conversation above describes the use of commisive speech act in the form of offering and refusing. The utterance which is spoken by Duke of Weaselton 'I offer you, your first dance as a queen' means that he offers to Elsa as a new queen in her coronation day to have a dance with him. The dance is used to congratulate her who took the throne.

The next utterance which is delivered by Elsa 'I don't dance' also shows the use of commisive in the form of refusing. Elsa try to refuse Duke of Weaselton's offer to dance. She is afraid since she has a magical power in her hand. She thought that when somebody touch her, they become hurt. So, she chose to refuse.

\section{CONCLUSION}

After analysing and presenting the data, the writers would like to conclude that there are four types of speech act which occur on film entitled Frozen. Those types are representative, expressive, directive, and commisive. From the data, it clearly seen that the most frequent occurrence of speech acts found in Walt Disney film entitled Frozen is directive. Children can imitate and adopt those utterances which indicate one or more types of speech act. It gives the contribution to the children language acquisition about how to state the belief, how to express the psychological state, how to get someone to do something, and how to commit the future action. 


\section{Acknowledgment}

All praises be to Allah SWT, the Almighty and the Most Merciful for all the blessing without which we would never been able to finish this research. We would like to express our sincere appreciation to those who have supported in the research. Firstly, Ministry of Research, Technology, and Higher Education, who fully funds this research. Secondly, all leaders in Widya Dharma University who encourages the writers to conduct the research. Thirdly, my team member who is always being cooperative to finish this research. Finally, we realize that this research is far from being perfect even though we have tried the best. We will be glad to get some suggestions to this research. However, we hope that this research will give some contributions to the language studies and also human life.

\section{References}

Austin, J.L. (1962). How to do things with words. Oxford: Oxford University Press.

Bogdan, R. and Taylor, S. J. (1975). Introduction to qualitative research method. Canada: John Wiley \& Sons.

Bogdan, R. and Biklen, S. K. (1982). Qualitative research for education: an introduction to theory and methods. Massachusetts: Newbury House.

Cruse, Alan. (2006). A glossary of semantics and pragmatics. Finland: Edinburgh University Press.

Cutting, J. (2008). Pragmatics and discourse: a resource book for students. New York: Routledge.

Finnegan, E., Blair, D. and Collin, P. (1997). Language: its structure and use. $2^{\text {nd }}$ Ed. New York: Harcourt Brace\& Co.

Grundy, P. (2008). Doing pragmatics. London: Hodder Education.

Leech, G. (1983). Principles of pragmatics. New York: Addison Wesley Longman Publishing.

Mey, J. (2001). An introduction of pragmatic. Oxford: Blackwell Publications Inc.

Nunan, D. (1993). Introducing discourse analysis. London: Penguin English.

Widdowson, H.G. (1996). Linguistics. Oxford: Oxford University Press.

Yule, G. (1996). Pragmatics. Oxford: Oxford University Press. 